\title{
EFEKTIVITAS STRATEGI PERMAINAN DALAM MENGEMBANGKAN SELF-CONTROL SISWA
}

\author{
Maya Masyita Suherman \\ Email: mayasuherman57@gmail.com \\ Guru Bimbingan dan Konseling
}

\begin{abstract}
Background of the research is the low of students' self-control in the school environment. The low of ability to control themselves in students can lead to self-destructive behavior and others. One way that can be done to develop students'self-control is a game's strategy. The study aims to test the effectiveness of the game's strategy in developing students' self-control. The research was used a quantitative approach with Quasi-Experimental method with the research design of nonequivalent control groups design. The population in the study were all fourth grade students of SD Laboratorium Percontohan UPI on academic year 2015/2016. Samples were students of class IV A and IV B of SD Laboratorium Percontohan UPI that is determined by random sampling. Data were analyzed with nonparametric test statistics. The research instrument used is the scale of self-control. Results showed empirically that game' strategy is proven effective to develop self-control students. The effectiveness is marked by an increased of posttest scores of students in the experimental group and a good responses of student. Research recommendations addressed to: (1) BK teachers to work closely with the subject teacher in case of training to master the basic techniques of playing so subject teachers can deliver the subject matter in the form of a more varied game and make students more active; and (2) further research to develop the factors that influence self-control in order to know the development of self-control in a comprehensive manner.
\end{abstract}

Keywords: Self-Control, Students of Elementary School, Strategy of Games

\begin{abstract}
ABSTRAK
Penelitian dilatarbelakangi oleh permasalahan rendahnya self-control siswa di lingkungan sekolah. Rendahnya kemampuan mengontrol diri pada siswa dapat berakibat pada perilaku yang merusak diri sendiri dan orang lain. Salah satu cara yang dapat dilakukan untuk mengembangkan self-control siswa adalah dengan strategi permainan. Penelitian bertujuan menguji efektivitas strategi permainan dalam mengembangkan self-control siswa.Penelitian menggunakan pendekatan kuantitatif dengan metode Quasi-Eksperimen dengan desain penelitian nonequivalent kontrol groups design. Populasi dalam penelitian adalah seluruh siswa kelas IV SD Laboratorium Percontohan UPI tahun ajaran 2015/2016. Sampel penelitian adalah siswa kelas IV A dan IV B SD Laboratorium Percontohan UPI yang ditentukan secara randomsampling. Data dianalisis dengan statistik uji nonparametrik. Instrumen penelitian yang digunakan adalah skala self-control. Hasil penelitian menunjukkan secara empirik, strategi permainan teruji efektif untuk mengembangkan self-control siswa. Efektivitas ditandai dengan meningkatnya skor posttest siswa pada kelompok eksperimen dan respon siswa yang baik. Rekomendasi penelitian ditujukan kepada: (1) guru BK untuk dapat bekerja sama dengan guru mata pelajaran dalam hal pelatihan menguasai teknik dasar bermain agar guru mata pelajaran dapat memberikan materi pelajaran dalam bentuk permainan yang lebih variatif dan membuat siswa lebih aktif; dan(2) peneliti selanjutnya untuk mengembangkan faktor-faktor yang mempengaruhi selfcontrol agar dapat diketahui perkembangan self-control secara komprehensif.
\end{abstract}

Kata kunci: self-control, siswa sekolah dasar, strategi permainan

\section{PENDAHULUAN}

Self-control dibutuhkan agar individu dapat membimbing, mengarahkan dan mengatur segi-segi perilakunya yang pada akhirnya mengarah kepada konsekuensi positif yang diinginkan. Self-control memberikan keputusan melalui pertimbangan sadar untuk mengintegrasikan tindakan yang akan dilakukan untuk mencapai hasil yang diinginkan atau tujuan yang ditentukan oleh individu itu sendiri. Hurlock (2004, hlm. 225) menjelaskan individu yang memiliki self-control memiliki kesiapan diri untuk berperilaku sesuai dengan tuntutan norma, adat, nilai-nilai yang bersumber dari ajaran agama dan tuntutan lingkungan masyarakat tempat ia tinggal, emosinya tidak lagi meledak-ledak dihadapan orang lain, melainkan menunggu saat dan tempat yang lebih tepat untuk mengungkapkan emosinya 
dengan cara-cara yang lebih diterima. Apabila individu mampu menghindari situasi-situasi yang dapat memicu sifat-sifat negatif berarti individu tidak membiarkan dirinya ikut pada kecenderungan-kecenderungan untuk bereaksi secara negatif. Perilaku kejahatan, nakal dan agresif merupakan beberapa contoh perilaku-perilaku yang merusak dan merugikan diri sendiri dan orang lain. Menurut Thomas, Nathan \& Finkel (2012, hlm. 22) kontrol diri dapat membantu seseorang untuk berperilaku sesuai dengan standar pribadi atau sosial yang dapat menghindari agresi. Semakin tinggi self-control seseorang maka semakin rendah agresivitasnya. Sebaliknya semakin rendah self-control maka semakin tinggi agresivitasnya.

Menurut ASCA (2012), self-control merupakan salah satu kompetensi yang perlu dimiliki oleh siswa kelas IV SD, kompetensinya adalah "mereviu konsep tentang dirinya sebagai pengendali bagi pikiran, perasaan dan perilakunya sendiri" sehingga siswa SD dapat mengendalikan dirinya agar terhindar dari kenakalankenakalan yang cukup memprihatinkan. Sejalan dengan yang dikemukakan oleh NASP (1998) bahwa self-control merupakan keterampilan penting yang harus dipelajari oleh anak. Self-control menjadi acuan atas tindakan yang dilakukan. Anak-anak yang tidak membuatpilihan untukperilaku mereka sendiri, melainkan bergantung pada anak-anak yang lain, orang tua, guru, atau orang dewasa untuk membuat pilihan bagi mereka, tidak belajar self-control. Anak-anak inidapat mengikuti pilihan yang buruk dari orang lain dan tidak bertanggung jawab atas konsekuensi dari perilaku mereka.

Bettencourt et al. (2006, hlm. 758) mengemukakan orang yang mengalami kesulitan dengan self-control akan dapat mendorong untuk berprilaku agresif. William et al. (2005, hlm. 728) mengemukakan macam-macam bentuk agresi adalah agresi fisik yaitu misalnya memukul, menendang, mencubit, ancaman kekerasan, mengambil obyek dan sebagainya. Agresi menurut Murray (dalam Hall \& Lindzey, 1993, hlm. 35) adalah suatu cara untuk melawan dengan kekerasan dengan tidak adil, melukai, membunuh orang lain dan menghukum orang lain.

Komisi Perlindungan Anak Indonesia (KPAI) (Harian Terbit,2015) menyatakan, kekerasan pada anak selalu meningkat setiap tahun. Hasil pemantauan KPAI dari 2011 sampai 2014, terjadi peningkatan yang signifikan. "tahun 2011 terjadi 2178 kasus kekerasan, 2012 ada 3512 kasus, 2013 ada 4311 kasus, 2014 ada 5066 kasus", 5 kasus tertinggi dengan jumlah kasus per bidang dari 2011 hingga april 2015. Pertama, anak berhadapan dengan hukum hingga April 2015 tercatat 6006 kasus. Selanjutnya kasus pengasuhan 3160 kasus, pendidikan 1764 kasus, kesehatan dan napza 1366 kasus serta pornografi dan cybercrime 1032 kasus. Selain itu anak bisa menjadi korban ataupun pelaku kekerasan dengan lokus kekerasan pada anak ada 3 , yaitu di lingkungan keluarga, sekolah dan masyarakat. 78 persen anak menjadi pelaku kekerasan dan sebagian besar karena mereka pernah menjadi korban kekerasan sebelumnya atau pernah melihat kekerasan yang dilakukan kepada anak lain dan menirunya. Anak-anak rentan menjadi korban kekerasan justru dilingkungan rumah dan sekolah.

Jenis kenakalan dengan fenomenafenomena yang telah dikemukakan dapat direduksi dengan mengembangkan kontrol diri siswa. Chapple (2005) mengemukakan terdapat korelasi antara variabel kontrol diri dan kenakalan remaja. Chapple menyebutkan bahwa korelasi antara perilaku kenakalan dengan kontrol diri banyak dijembatani oleh konformitas pada teman sebaya, selain itu faktor-faktor eksternal yang memengaruhi adalah keluarga dan lingkungan tempat tinggal. Kenakalan remaja yang semakin meningkat dewasa ini disebabkan karena individu belum memiliki kontrol diri yang baik. Apabila keterampilan kontrol diri 
dikembangkan sejak dini, maka remaja akan mampu mengendalikan diri dari perilaku-perilaku nakal yang dapat merusak kehidupannya di masa depan.

Berdasarkan realitas di atas maka dibutuhkan sebuah strategi bimbingan dan konseling yang sesuai. Bimbingan dan konseling memiliki peranan penting untuk membantu siswa SD agar memiliki selfcontrol yang baik. Strategi layanan BK yang dapat dilakukan untuk mengembangkan selfcontrol siswa sekolah dasar adalah layanan dasar dengan strategi bimbingan kelompok, karena menurut Hurlock (1989, hlm. 146) pada usia sekolah dasar anak diharapkan memperoleh dasar-dasar pengetahuan yang dianggap penting untuk keberhasilan penyesuaian diri pada kehidupan dewasa dan mempelajari keterampilan penting tertentu, sehingga siswa sejak dini diberikan keterampilan mengontrol dirinya agar dapat menghindari perilaku-perilaku nakal yang akan berdampak negatif bagi kehidupan remaja dan dewasa nanti.

Bimbingan kelompok memiliki sifat yang beragam, mulai dari yang bersifat informatif sampai pada yang sifatnya teraupetik. Sedangkan dalam prakteknya bimbingan kelompok dapat dilakukan dengan berbagai teknik seperti diskusi, latihan, karya wisata, homerome program, dan sosiodrama serta simulasi permainan.

Permainan memberikan kesempatan untuk memperoleh pengetahuan tentang sesuatu, melatih imajinasi, memberikan peluang untuk berinteraksi dengan lingkungan sekitar, serta untuk mengekspresikan diri dengan cara-cara yang dapat diterima secara sosial. Menurut Solehuddin (2000, hlm. 84) bermain dapat dipandang sebagai suatu kegiatan yang bersifat voluntir, spontan, terfokus pada proses, memberi ganjaran secara instrinsik, menyenangkan, aktif dan fleksibel. Semakin suatu aktivitas memiliki ciri-ciri tersebut, berarti aktivitas itu semakin merupakan bermain. Menurut Blum (dalam Rusmana, 2009b, hlm. 14) permainan pada intinya bersifat sosial dan melibatkan belajar dalam memperoleh pengalaman serta mematuhi aturan-aturan yang sudah ditentukan, pemecahan masalah, disiplin diri, kontrol emosional serta adopsi peran-peran pemimpin dalam kegiatan permainan yang semuanya itu merupakan komponen terpenting dari sosialisasi dengan lingkungan sekitarnya. Hal ini diperkuat oleh pendapat Solehuddin (2000, hlm. 87) yang mengatakan bahwa dilihat dari sifat dan sasaran kegiatannya, bermain memang memiliki beberapa ciri yang kontradiktif dengan belajar.

Penelitian terdahulu yang menjadi landasan bagi efektivitas strategi permainan dalam mengembangkan self-controlsiswa penelitian yang dilakukan oleh Haeny (dalam Ambarita, 2010 hlm. 50). Program bimbingan kelompok melalui teknik permainan terdapat perbedaan yang signifikan penyesuaian diri peserta didik sebelum dan sesudah diberi bimbingan kelompok. Senada dengan hasil penelitian kuasi ekperimen Ambarita (2015) yang menyatakan bahwa teknik permainan efektif untuk meningkatkan penyesuaian diri peserta didik kelas IV Sekolah Dasar Taruna Bakti. Rennie, L. Robyn (2000) mengungkapkan efektivitas terapi bermain berupa konseling kelompok dan konseling individual membantu anak dalam mengahadapi berbagai masalah penyesuaian diri, terutama masalah penyesuaian yang berasal dari sekolah yang di dalamnya dapat meningkatkan konsep diri anak dan mengurangi perilaku agresi dan kenakalan pada anak usia sekolah dasar. Hasil penelitian Hamonangan (2014) layanan bimbingan kelompok melalui permainan efektif untuk meningkatkan kepercayaan diri siswa.

Hasilpenelitiantersebutjugadidukungoleh studi pendahuluan dengan hasil ITP siswa kelas $\mathrm{V}$ menunjukkan bahwa kematangan emosional siswa $22,74 \%$ dan kesadaran tanggung jawab 15,84\% yang artinya bahwa siswa di SD Laboratorium Percontohan UPI tergolong memiliki self control yang rendah 
ditandai dengan rendahnya kemampuan siswa dalam mengendalikan emosi, menjaga stabilitas emosi, rendahnya kesadaran bertanggung jawab atas tindakan pribadi dan disiplin yang rendah.

White, Flynt dan Landert (dalam Jennifer $\mathrm{dkk}$, 2010) menekankan bahwa konselor sekolah dasar perlu menyadari kebutuhan perkembangan siswa dan memahami bahwa permainan merupakan aktivitas alami anakanak. Konselor sekolah dapat menggunakan strategi permainan untuk perubahan perilaku pada anak. Permainan merupakan kegiatan yang menyenangkan bagi mereka yang terlibat didalamnya, dan sering melibatkan kreativitas, fleksibilitas, pengambilan resiko, rasa ingin tahu, serta kemampuan beradaptasi. Menurut Rusmana (2009a hlm. 27) mekanisme pelaksanaan permainan pada proses bimbingan menggunakan metode pembelajaran ekperiensial (experienciallearning). Metode pembelajaran eksperiensial adalah metode mengajar yang mengakomodasi tiga jenis pembelajaran, yaitu kognitif, emosional dan fisik.

Dalam permainan tidak hanya terdapat unsur kegembiraan dan kesenangan saja, karena melalui bermain anak akan belajar berbagai hal yang ada disekelilingnya secara menyenangkan sehingga anak menyelidiki dan memperoleh pengalaman yang kaya baik dengan dirinya sendiri, lingkungan maupun orang lain disekitarnya. Menurut penelitian Gaulden (dalam Rennie, 2000, hlm. 9) teknik permainan dalam setting kelompok efektif dalam perkembangan konseling anak-anak di sekolah dasar yang bermanfaat untuk membantu anak yang memiliki masalah dengan penyesuaian diri di dalam kelas.

Dalam bimbingan kelompok ini anggota yang dihadapi bukanlah bersifat individual, tetapi terdiri atas beberapa orang yang akan memanfaatkan dinamika kelompok secara bersama-sama untuk membahas topik/permasalahan dan belajar untuk lebih mengembangkan dirinya termasuk mengembangkan self-control mereka.
Sehingga dengan adanya hubungan yang interaktif tersebut anggota kelompok akan merasa lebih mudah dan leluasa, karena anggotanya merupakan teman sebaya mereka. Selain itu dengan melakukan bimbingan kelompok yang memanfaatkan dinamika kelompok ini, siswa juga belajar untuk memahami dan mengendalikan diri sendiri, memahami orang lain, memahami kehidupan lingkungannya, dan dapat meningkatkan self-controlnya.

Dengan demikian perpaduan bimbingan kelompok melalui dinamika kelompok yang didalamnya terdapat permainan kelompok dimungkinkan dapat membantu meningkatkan self-control siswa, karena dalam kelompok yang efektif diharapkan adanya kerjasama, etiket dan sikap yang baik pada orang lain, serta kemandirian dari setiap anggotanya. Permainan dan bimbingan kelompok merupakan perpaduan yang harmoni, karena keduanya memiliki kesamaan prinsip yaitu kebersamaan, maka dengan kebersamaan inilah akan terbentuk suatu kelompok yang dinamis dan diharapkan dalam kelompok dapat terbentuk perilaku siswa yang positif, yakni kemampuan mengontrol diri.

\section{Konsep dasar self-control dan strategi permainan}

Self-control merupakan suatu kecakapan individu dalam kepekaan membaca situasi diri dan lingkungannya, selain itu juga kemampuan untuk mengontrol dan mengelola perilaku sesuai dengan situasi dan kondisi agar sesuai dengan orang lain, menyenangkan orang lain, dan menutupi perasaannya (Ghufron \& Risnawita, 2010). Messina (dalam Ghufron \& Risnawita, 2010) menambahkan bahwa kontrol diri merupakan tingkah laku yang terfokus pada keberhasilan mengubah pribadi, menangkalselfdestructive, perasaan outonomi, atau bebas dari pengaruh orang lain, kebebasan menentukan tujuan, kemampuan untuk memisahkan perasaan dan pikiran rasional dan tingkah laku yang 
terfokus pada tanggung jawab pribadi. Lazarus juga mengemukakan (1976, hlm. 34) bahwa kontrol diri merupakan pemahaman tentang pengungkapan diri baik, baik pengungkapan diri positif maupun negatif, sehingga individu dapat menyadari hal-hal yang bisa membangkitkan ekspresi-ekspresi positif maupun negatif dalam diri. Pendapat lain dikemukakan oleh Carter \& Alex (2012, hlm. 5) bahwa dalam diri seseorang terdapat suatu sistem pengaturan diri (self regulation) yang memusatkan perhatian pada pengontrolan diri (self-control). Proses pengontrolan diri ini menjelaskan bagaimana diri mengatur dan mengendalikan perilaku dalam menjalani kehidupan sesuai dengan kemampuan individu dalam mengendalikan perilaku. Apabila individu itu mampu mengendalikan perilakunya dengan baik maka individu tersebut dapa menjalani kehidupan dengan baik. Kesimpulan dari beberapa pengertian tentang kontrol diri adalah kemampuan untuk mengendalikan diri, mengontrol dorongan-dorongan negatif dan mengendalikan perilaku kearah yang positif.

Permainan memberikan kesempatan untuk memperoleh pengetahuan tentang segala sesuatu, melatih imajinasi, memberikan peluang untuk berinteraksi dan penyesuaian diri dengan lingkungan sekitar, serta untuk mengekspresikan agresi dalam cara-cara yang dapat diterima secara sosial. Menurut Scrok dan Blum (Rusmana, 2009b hlm. 4) permainan pada intinya bersifat sosial dan melibatkan belajar dalam memperoleh pengalaman serta mematuhi aturan-aturan yang sudah ditentukan, pemecahan masalah (problemsolving), disiplin dalam diri, kontrol emosional, serta adopsi peran-peran pemimpin dalam pelaksanaan kegiatan permainan dan pengikut yang semuanya itu merupakan komponen-komponen terpenting dalam sosialisasi dengan lingkungan sekitarnya. Permainan merupakan salah satu teknik yang dipakai dalam bimbingan dan konseling khususnya terhadap anak karena terkadang anak tidak mampu mengatakan apa yang dirasakan tetapi hanya bisa menunjukkan perasaan dalam bentuk perilaku.

Strategi permainan sebagai salah satu teknik dalam bimbingan kelompok maksudnya adalah kegiatan yang dilakukan oleh konselor/guru BK teradap sejumlah siswa sesuai dengan tahapan dan prosedur bimbingan kelompok yang didalamnya terdapat unsur permainan.

Langkah-langkah permainan dalam bimbingan kelompok ini mengikuti prosedur pelaksanaan bimbingan kelompok pada umumnya, hanya saja dengan menggunakan teknik permainan, yaitu: fase pemanasan, fase tindakan dan fase integrasi. Tahap-tahap yang terdiri dari empat fase tersebut diuraikan sebagai berikut: (1) Fase awal (pemanasan) yaitu tahap pengakraban dan persiapan untuk melakukan aktivitas permainan; (2) Fase transisi; (3) Fase tindakan (tahap inti) yaitu tahap pelaksanaan permainan; dan (4) Fase integrasi (tahap akhir) berupa kegiatan diskusi kelompok dan penutupan.

Self-control yang dimaksud dalam penelitian ini adalah kemampuan siswa kelas IV SD Laboratorium Percontohan UPI dalam memonitor dirinya sendiri, mengontrol pikiran, mengambil keputusan dan mengontrol perilaku sesuai dengan situasi dan kondisi sehingga tahu apa kekurangan yang ada pada individu, serta senantiasa berusaha untuk menguatkan dirinya secara positif.Kemampuan siswa SD kelas IV Laboratorium Percontohan UPI dalam mengontrol diri ditandai dengan aspek kontrol perilaku (behavior control), kontrol kognitif (cognitive control), dan kontrol keputusan (decisional control).

Strategi permainan adalah perencanaan yang berisi rangkaian kegiatan yang didesain untuk mengembangkan self-control siswa kelas IV SD Laboratorium Percontohan UPI Tahun Ajaran 2015/2016.Strategi permainan yang dimaksud dalam penelitian ini yaitu suatu teknik bimbingan dan konseling yang 
dilakukan secara berkelompok dimana peneliti menggunakan permainan-permainan yang dapat mengembangkan self-control anggota kelompok. Dalam pelaksanaan kegiatan ini dilaksanakan oleh semua anggota dengan aturan dan ketentuan yang berlaku, dengan suasana yang rileks dan menyenangkan.

Tujuan penelitian adalah menghasilkan data empirik mengenai efektivitas strategi permainan dalam mengembangkan selfcontrol siswa kelas IV SD Laboratorium UPI Tahun Ajaran 2015/2016. adapun tujuan khusus yang ingin dicapai ialah: (1) Memperoleh gambaran profil self-control Siswa Kelas IV SD Laboratorium UPI Tahun Ajaran 2015/2016; (2) Memperoleh rancangan strategi permainan dalam mengembangkan self-control siswa; dan (3) Mengetahui efektivitas strategi permainan dalam mengembangkan self-control siswa.

\section{METODE PENELITIAN}

Pengumpulan data pada penelitian dilaksanakan dengan menggunakan angket, jurnal harian yang diisi oleh siswa dan dengan observasi.

Instrumen yang digunakan dalam penelitian dikembangkan berdasarkan pengembangan dan perumusan teori mengenai self-control. Pada penelitian ini dikembangkan atas dasar perspektif teori self-control dari Averill (1973).

\section{Analisis Data}

Dalam melakukan uji efektivitas kaitannya dengan intervensi strategi permainan dalam mengembangkan self-control siswa, yang harus dipenuhi adalah dengan melakukan uji perbandingan, yaitu selisih skor antara pretest dan postest kontrol diri siswa, sehingga dari hasil analisis tersebut didapat hipotesis penelitian. Teknik analisis data yang digunakan dalam penelitian ini menggunakan uji U Mann-Whitney melalui bantuan program SPSS version 18.0. uji $U$ Mann-Whitney merupakan pengujian yang digunakan pada dua sampel independen non parametrik.

\section{Prosedur Penelitian}

Langkah awal dari penelitian ini adalah observasi ke sekolah yang akan dijadikan sasaran penelitian. Obeservasi bertujuan untuk memeroleh gambaran langsung mengenai siswa, guru, sarana dan prasarana sekolah dan lingkungan sekolah serta permasalahan-permasalahan yang ada. Setelah menemukan permasalahan yang akan diteliti, kemudian dilanjutkan dengan mencari literature yang mendukung dalam penyususnan proposal penelitian dan instrument.

Pretest dilaksanakan dengan menyebarkan angket self-control pada siswa kelas IV SD Laboratorium Percontohan UPI. Pretest dilakukan sebagai tes awal untuk mendapatkan data mengenai gambaran umum kontrol diri siswa kelas IV.

Pemilihan kelompok eksperimen dan kelompok kontrol dilakukan secara simple random sampling. Adapun kelas yang terpilih menjadi kelompok eksperimen adalah kelas IV A dan kelas kontrol adalah kelas IV B.

Pemberian perlakuan / treatmen dilakukan sebanyak lima kali dan setiap selesai pemberian treatmen siswa diberikan jurnal harian untuk melihat hasil dari treatmen yang diberikan.

Pada akhir pertemuan siswa diberikan posttest. Posttest diberikan setelah dilaksanakannya treatmen sebanyak lima kali. Hasil tes tersebut selanjutnya diolah dan dianalisis oleh peneliti.

\section{HASIL PENELITIAN}

Hasil penelitian menunjukkan bahwa hampir setengah dari keseluruhan jumlah siswa kelas IV SD Laboratorium Percontohan UPI Tahun Ajaran 2015/2016 memiliki tingkat self-control sedang, dan sisanya berada pada kategori tinggi dan rendah dengan persentase yang seimbang.

Hasil pretest seluruh aspek self-control 
terhadap siswa kelas IV SD Laboratorium Percontohan UPI ditemukan bahwa aspek cognitive control merupakan aspek yang paling dominan yaitu sebesar $33 \%$ pada kategori tinggi. Aspek cognitive control adalah kemampuan individu dalam mengelola informasi yang tidak diinginkan dengan cara menginterpretasi, menilai, atau menggabungkan suatu kejadian dalam suatu kerangka kognitif sebagai adaptasi psikologis atau untuk mengurangi tekanan. Aspek ini terdiri dari dua komponen, yaitu memperoleh informasi dan melakukan penilaian. Dengan informasi yang dimiliki oleh individu mengenai suatu keadaan yang tidak menyenangkan, individu dapat mengantisipasi keadaan tersebut dengan berbagai pertimbangan. Melakukan penilaian berarti individu berusaha menilai dan menafsirkan kedaan atau peristiwa dengan cara memperhatikan segi-segi positif scara objektif.

Rata-rata post-test kelompok eksperimen sejumlah 32,87 dan jumlah posttest kelompok kontrol adalah 16,80. Hal ini memperlihatkan bahwa ternyata jumlah rata-rata posttest kelompok eksperimen lebih tinggi daripada jumlah posttest kelompok kontrol. Dengan demikian $\mathrm{H}_{0}$ ditolak yang artinya terdapat perbedaan antara rata-rata kelompok eksperimen dengan kelompok kontrol, sehingga dapat disimpulkan bahwa strategi permainan efektif dalam mengembangkan self-control siswa.

\section{SIMPULAN}

Berdasarkan temuan penelitian dapat dirumuskan simpulan sebagai berikut:

1. Gambaran umum self-control siswa kelas IV SD Laboratorium Percontohan UPI tahun ajaran 2015/2016 berada pada tingkat kategori sedang, artinya siswa menunjukkan kemampuan yang cukup baik dalam megendalikan situasi berdasarkan faktor dari dalam diri dan lingkungan, mampu mengetahui cara menghadapi stimulus yang tidak dikehendaki, melakukan penilaian, meskipun masih takut memilih bebagai kemungkinan tindakan dan hanya mampu memilih sedikit hasil dari tindakan.

2. Rancangan strategi permainan dalam mengembangkan Self-control dilaksanakan dalam tujuh sesi. Sebelum intervensi dilakukan, diawali dengan pretest terlebih dahulu dan setelah ke enam sesi dilaksanakan, siswa diberi posttest. Pelaksanaan sesi intervensi dimulai dengan kemampuan cognitivecontrol terlebih dahulu kemudian dilanjutkan dengan decisional control dan terakhir behavioral control.

3. Strategi permainan efektif dalam mengembangkan self-control siswa. Efektivitas ditandai dengan meningkatnya skor posttest siswa pada kelompok eksperimen dan respon siswa yang baik, selama mengikuti sesi intervensi.

\section{DAFTAR RUJUKAN}

Ambarita. (2015). Efektivitas teknik permainan untuk meningkatkan penyesuaian diri peserta didik sekolah dasar. (Tesis). Sekolah Pasca Sarjana, Universitas Pendidikan Indonesia, Bandung.

ASCA. (2012). National Model : A framework for school counseling programs. [online].Tersedia :www. schoolcounselor. (15 Februari 2014).

Averill. (1973). Personal control over aversive stimuli and its relationship to stress. Psychological Bulletin, 80 (4), hlm. 286-303.

Bettencourt Ann, et al. (2006). Personality and aggressive behavior under provoking and neutral conditions: a meta-analytic review. Journal of Psychological: Bulletin by the American Psychological Association, 132 (5), hlm. 751-777.

Chapple Hay, Rian C. Meldrum \& Alex R. Piquero. (2012). Negatif cases in the nexus between self-control, sosial bonds and delinguency. Journal of Youth Violence and Juvenile Justice, 2 (1), hlm. 3-25. 
Ghufron, M.R., \& Risnawita, R. (2010). Teori-teori psikologi. Jogjakarta: Ar Ruz Media.

Gufron, M. Nur. (2003). Hubungan kontrol diri dan persepsi remaja teradap penerapan disiplin orangtua dengan prokrastinasi akademik. [online]. Diakses dari http://www.damandiri.or.id. (24 November 2014).

Hamonangan, H.R. (2014). Efektivitas layanan bimbingan kelompok melalui permainan untuk meningkatkan kepercayaan diri siswa. (Tesis). Sekolah Pasca Sarjana, Universitas Pendidikan Indonesia, Bandung.

Hall C.S \& Lindzey, G. (1993). Teori-teori kepribadian (klinis). Yogyakarta: Kanisius.

Harian Terbit.(2015). Kasus kekerasan pada anak tahun 2015. [online]. Tersedia: http://books.google.co.id . (15Februari 2014)

Hurlock B, Elizabeth. (2004). Alih Bahasa: Istiwidayanti\&Soedjarwo. Psikologi perkembangan suatu pendekatan sepanjang rentang kehidupan. Jakarta: Erlangga.

Hurlock B, Elizabeth. (1981).Developmental psychology, a life-span approach. New Delhi: tata McGraw-Hill Publishing Company Ltd.

Hurlock B, Elizabeth. (1980).Psikologi perkembangan. Jakarta: Erlangga.

Jennifer, dkk. (2010). Child centered play therapy research. Canada: John Wiley \& Sons, Inc. All rights reserved.

Lazarus, R.S. (1976). Pattern of adjusmen. Tokyo: McGraw-Hill. Kogakusha, Ltd.

National Association of School Psychologists. (2002). Handout was published on NIVT website. Amerika: NASP

National Association of School Psychologists. (1998). Self-control skills for children. Amerika: NASP.

Rennie, R. L. (2000). A comparison study of the effectiviness of individual and group play therapy in treating kindergarten children with adjustment problems. (Disertation). School of post graduate, University of North Texas.

Rusmana, N. (2009b). Permainan (play \& games): permainan untuk para pendidik, pembimbing, pelatih dan widyaiswara. Bandung: Rizqi Press.

Rusmana, N. (2009a). Bimbingan dan konseling kelompok di sekolah: metode, teknik dan aplikasi. Bandung: Rizqi Press.

Solehuddin, M. (2000). Konsep dasar pendidikan prasekolah.Bandung: Rizqi Pres 